\title{
Performance Evaluation of Mobile Liquid Cooled Thermoelectric Refrigeration System for Storage- cum-Transportation of Fruits and Vegetables
}

Prasad Chavan ( $\nabla$ erprasad.chavan@gmail.com )

Punjab Agricultural UniversityLudhiana

Gagandeep Kaur Sidhu

Punjab Agricultural UniversityLudhiana

Physical Sciences - Article

Keywords: cold chain management, eco-friendly refrigeration, quality attributes, thermoelectric refrigeration

Posted Date: May 29th, 2021

DOI: https://doi.org/10.21203/rs.3.rs-543847/v1

License: (a) (1) This work is licensed under a Creative Commons Attribution 4.0 International License. Read Full License 


\section{Abstract}

The performance of a liquid-cooled thermoelectric refrigeration (LCTR) system for the storage of summer fruits and vegetables, viz., bitter gourd, okra, mango, and papaya indicated impressive results for physiological loss in weight, firmness and colour values, and overall acceptability of the crop. The LCTR system significantly reduced $(p<0.0001)$ the physiological loss in weight $(P L W)$ of bitter gourd, okra, mango, and papaya to $11.51 \%, 10.99 \%, 12.29 \%$, and $19.17 \%$, respectively, compared to conventional ambient storage of the crop. A lesser change in colour was observed for the crop subjected to LCTR, recording $14.04,11.46,16.41$, and 23.68 for bitter gourd, okra, mango, and papaya, respectively. All the crops witnessed a nonsignificant effect $(p<0.0001)$ on the quality attributes of the crop stored in LCTR and a vapour compression refrigeration system. LCTR enabled a pronounced increment in the shelf life of bitter gourd, okra, mango, and papaya by $7,8,10$, and 13 days, respectively, compared to the storage at ambient conditions. The system is economical, has a higher coefficient of performance $(0.85)$ compared to the coefficient of performance (COP) of the existing thermoelectric refrigeration system, and maintains the freshness and quality of perishable agricultural produce during marketing and transportation.

\section{Introduction}

The global food production of the last 50 years has witnessed a significant increment of almost threefold in the face of a twofold increase in global population. Despite this progress, one in eight people around the globe remains chronically undernourished [1]. In the Indian context, the per capita availability of fruits is limited to $107 \mathrm{~g} /$ day against the recommended level of $120 \mathrm{~g} /$ day [2]. Despite an impressive increase in production, post-harvest losses at various stages of supply chain management, which amount to 20$60 \%$ of the food produced across the world, have led to the uneven distribution and shortage of the qualitative food supply [2-4]. One of the major reasons for this food waste and food loss is the lack of an efficient cold chain infrastructure from the farm to the fork, which includes refrigerated transport, pack houses, collection centers, and cold storage. Major agricultural post-harvest losses accounted in India were of the order of 9265.1 million Indian rupees [5], of which, $4.58-15.88 \%$ was contributed by fruits and vegetables. Moreover, the physical loss of food has multiple consequences in association with the wastage of inputs such as water, fertilizer, electricity, human efforts, and precious time. To fulfill the global food demand, along with increasing food production, efficient supply chain management has to be adopted and cold store preservation of fruits and vegetables from immediately after harvest to the end consumer has to be encouraged [6]. Cold chain management is the crucial operation that takes out heat energy from the food and lower temperature is maintained throughout the storage life of the food.

The basic principle of refrigeration preservation is to reduce the temperature of the food and maintain that temperature to a level such that the detrimental changes such as the growth of microorganisms, ripening, browning reaction, pigment degradation, and moisture loss are stopped or considerably reduced [7]. Cold preservation slows down not only the biological and chemical changes but also the physical and microbiological changes that cause spoilage of the food [8]. The modified atmosphere along with lowtemperature storage controls the natural process of metabolism of the fruits and vegetables in 
conjunction with the reduced gas exchange through a barrier results in satisfactory shelf-life extension and the maintenance of the physicochemical constituents of produce [9-11]. The refrigeration system provides very effective and efficient cold chain infrastructure to the freshly harvested commodities for maintaining freshness with extended shelf life. As a result, it extends the storage life of food up to several weeks or a month without deteriorating the quality of fresh produce till it reaches the end consumer [12]. By way of maintaining the physicochemical and nutritional quality of food for a longer period, the cold preservation technique not only reduces the food losses in physical form but also lessens the economic losses to the manufacturer as well as avoids the foodborne illness instigated by the multiplication of bacteria and microorganisms $[13,14]$. Thereby, the cold prevention technique maintains the availability of better-quality food produce in a distant market at a reasonable price while sustaining the circular food economy.

The chlorofluorocarbons (CFCs) and hydrochlorofluorocarbons (HCFCs) used as a refrigerant in the vapour compression refrigeration system contain chlorine which causes ozone layer depletion; whereas, although hydrofluorocarbons (HFCs) are chlorine-free, these are green-house gases that cause the global temperature rise. It has been reported that these gases have a global warming potential of a thousand times that of carbon dioxide [15]. According to United Nation Environment Program (UNEP) [16], refrigeration, air conditioning, and heat pumps annually contribute $40 \%$ of the $\mathrm{CO} 2$ equivalent emissions. It was estimated that almost $20 \%$ of the global warming impact was attributed due to the leakage of refrigerants into the atmosphere. An expert's summit in 2009 at the Food and Agriculture Organization (FAO) Headquarter in Rome concluded that the food demand of the rising population can only be met when investment in scientific research and development will be followed along with the best environmental services to save the products from pests and preserve the perishable produce until it reaches the consumers' table [17].

The thermoelectric refrigeration technique is a promising alternative because of its compactness, it's silent working as it does not involve a compressor, and because it has a wide range of temperatures [1820]. The thermoelectric devices convert electricity into heat and vice-versa, with rigid structure, good stability, high reliability, and no evolution of greenhouse gas. The thermoelectric devices can be used for the development of thermoelectric refrigeration systems which are based on the Peltier effect for removing heat by application of direct current (DC) across two dissimilar materials joined together generating a temperature difference [21]. The thermoelectric refrigerator mainly consists of $\mathrm{P}$ and $\mathrm{N}$-type semiconductors connected together and when Direct current is applied across them, one junction gets heated and the other is cooled. Evidence for the applicability of the thermoelectric cooling principle is available from the cooling of sensors in aerospace, portable picnic coolers, automobiles, aircraft drinking water cooler, etc. Efforts were also made by [22] for the design of a small-scale mobile thermoelectric refrigeration system for the storage of beverages. However, no evidence is available for the use of thermoelectric refrigeration for the refrigeration of horticultural crops.

So, to tackle the growing concern of food wastage due to the lack of scientific cold chain infrastructure for rural fruits and vegetable vendors and the simultaneous increasing demand for fresh fruits and 
vegetables, a thermoelectric refrigeration system was developed. The developed system has a larger storage capacity and a higher coefficient of performance (COP) of 0.85 , which is higher as compared to other available systems. A study was undertaken to evaluate the performance of a developed thermoelectric refrigeration system. The performance was evaluated based on changes in the physical and mechanical properties and shelf life extension of fruits and vegetables stored in the system, and the results were compared with the vapour compression refrigeration system and ambient storage condition.

\section{Materials And Methods}

\subsection{Design of Thermoelectric Refrigeration System}

A battery-operated thermoelectric refrigeration system of $0.3 \mathrm{KW}$ capacity was developed in the workshop of Punjab Agricultural University, Ludhiana. The cooling chamber of $100 \mathrm{~L}$ storage capacity $(80 \times 50 \times 50$ $\mathrm{cm}$ ) was designed with a $6 \mathrm{~cm}$ thickness and the inside volume of the chamber was reduced to $100 \mathrm{~L}$ by partitioning. The main components of the developed thermoelectric refrigeration system include the cooling chamber, Peltier and heat sink assembly, coolant water pipes, coolant water storage tank, $12 \mathrm{~V}$ electric battery, 12 V DC fan, fogger, temperature, and relative humidity indicator as shown in Figure 1.

The assembly of the liquid-cooled thermoelectric refrigeration system consisted of four thermoelectric modules (TEC $12706 \mathrm{~A}$ ), four aluminum liquid cooling heat sink blocks, an elastomeric nitrile rubber sheet for insulation, and two axial fans (12 V DC, $0.23 \mathrm{~A}$ ). Two fin-type air-cooled heat sinks were assembled facing side to side by riveting to make one heat sink of $20 \times 15 \times 8 \mathrm{~cm}$. The cold sides of all (four) Peltier modules were pasted onto the cold side heat sink using thermal paste. Thermal paste is made of a polymerized liquid matrix of silicone of high thermal conductivity, which maintains a positive heat sink seal facilitating efficient heat transfer from the electronic components to the heat sink. The hot side of each Peltier module was attached with a liquid-cooled sink. The clearance between the cold side and the hot side heat sinks was sealed using a $3 \mathrm{~mm}$ thick elastomeric nitrile rubber insulation sheet which presents migration of heat from the hot side heat sink to the cold side heat sink. The inlet and outlet of all heat sinks were connected in parallel to the water tank through a plastic pipe of $1 \mathrm{~cm}$ diameter. Normal water was used as a coolant and circulated through evaporators using a diaphragm pump (12 V DC) powered by an electric battery. One fin-type air-cooled heat sink was attached over the liquid-cooled heat sink blocks which supports the blocks as well as acts as an additional heat dissipation medium. The geometry of the liquid-cooled heat sink, connecting pipes, diaphragm pump, water tank, and the battery is shown in Figure 2.

The computer-aided exploded view of the assembly of the heat sink, Peltier modules, and the fan is shown in Figure 3. As thermoelectric modules were powered by a $12 \mathrm{~V} \mathrm{DC}$ electric current, the heat sink attached to the cold side of the module gets cooled and transfers heat to the hot side of the module. The axial fan attached to the cold side heat sink circulates cold air inside the cooling chamber as presented in Figure 3. Water from the container is circulated through the water jackets attached at the hot side of the 
Peltier module. Water absorbs heat from the hot side and dissipates to the environment in the cooling tower.

Post-harvest storage of most fruits and vegetables requires an atmosphere of high relative humidity to prevent the physiological loss in weight and shrinkage of the crops. For maintaining higher humidity inside the cooling chamber, a Rivulis Irrigation Fogger of pressure range 50-70 psi was installed inside the chamber and operated by a diaphragm pump ( $12 \vee \mathrm{DC})$ powered by an electric battery.

The developed refrigeration system can attain cooling temperature in the range of $15-17^{\circ} \mathrm{C}$ and relative humidity of $80-90 \%$ when loaded with $12 \mathrm{~kg}$ of fruits and vegetables and at ambient temperature in the range of 35 to $40{ }^{\circ} \mathrm{C}$. The detailed specifications of the developed refrigeration system have been presented in Table 1.

Table 1. Specifications of liquid cooled thermoelectric refrigeration system.

\begin{tabular}{|lll|}
\hline Sr. No. & Particular & Specification \\
\hline 1 & Overall dimension of LCTR & $145 \times 650 \times 120 \mathrm{~cm}$ \\
\hline 2 & Material of cooling chamber & Polyurethane \\
\hline 4 & Cooling capacity of LCTR & $0.31 \mathrm{KW}$ \\
\hline 5 & Dimension of cooling chamber & $45 \times 50 \times 50 \mathrm{~cm}$ \\
\hline 6 & Cold chamber storage capacity & 100 litre \\
\hline 7 & Peltier module & TEC $12706 \mathrm{~A} ;(12 \mathrm{~V} \mathrm{DC}, 6 \mathrm{~A})$ \\
\hline 8 & Number of Peltier modules & 4 \\
\hline 9 & Number of air cooled heat sink & 3 \\
\hline 10 & Number of water pump & 2 \\
\hline 11 & Number of fogger & 1 \\
\hline 12 & Electric battery & $1(160 \mathrm{Ah})$ \\
\hline 13 & Water tank capacity (I) & 15 \\
\hline 14 & Cooling capacity & Temp $15-17^{\circ} \mathrm{C} / \mathrm{RH} 80-90 \%$ \\
\hline 15 & Coefficient of Performance (COP) & 0.85 \\
\hline
\end{tabular}

\subsection{Vapour Compression Refrigeration System}

To compare the developed thermoelectric refrigeration system with commercially available refrigeration 
technology, a vapour compression refrigerator (Godrej \& Boyce Mfg Co Ltd. Mumbai, India) of 150 liter capacity, operated using isobutene refrigerant and powered by $230 \mathrm{~V}$ power was used in the present study.

\subsection{Storage Stability and Quality of Fruits and Vegetables}

The performance of the developed mobile thermoelectric refrigeration system was evaluated based on the storage stability of fruits and vegetables. The freshly harvested summer fruits and vegetables (mango, papaya, bitter gourd, okra) were procured from Punjab Agricultural University farm. A $3 \mathrm{~kg}$ sample of each crop was stored at thermoelectric refrigeration (temp $15-18{ }^{\circ} \mathrm{C}$ and $\mathrm{RH} 80-90 \%$ ), vapour compression refrigeration (temp $6-8{ }^{\circ} \mathrm{C}$ and $\mathrm{RH} 80-90 \%$ ), and ambient atmospheric (temp $35-40{ }^{\circ} \mathrm{C}$ and $\mathrm{RH} 40-50 \%)$ storage conditions, respectively. The storage stability of the commodities stored in the developed refrigeration system was compared with the vapour compression refrigeration system and under an ambient environmental condition. The system was evaluated based on physiological loss in weight, texture, colour, and physical appearance of the commodity stored in the system. The changes in the quality parameters of stored fruits and vegetables were evaluated on a daily basis. The procedure followed for the evaluation of quality parameters is explained next.

\subsubsection{Physiological Loss in Weight (PLW)}

Physiological loss in weight is the reduction in weight of commodity due to physico-chemical reactions taking place in food over a period of time. The physiological loss in weight was determined as per method described by [23].

\section{See formula 1 in the supplementary files.}

Where,

$\mathrm{W}_{1}$-Weight of sample on 0th day

$\mathrm{W}_{2}$-Weight of sample on nth day

\subsubsection{Determination of Firmness}

Firmness as one of the parameters of texture analysis measures the force required to penetrate a stainless steel probe inside the food crop and measured in Newton force $(\mathrm{N})$. The firmness of okra and bitter gourd was measured with the help of a texture analyzer machine (Make: Instron, TA-HDi). The compression test was performed using a $2 \mathrm{~mm}$ stainless steel probe [24]. The machine operating parameters selected for this test were:

Contact force - $100 \mathrm{~g}$

Test speed $-2.0 \mathrm{~mm} / \mathrm{s}$
Pre-test speed $-1.0 \mathrm{~mm} / \mathrm{s}$

Compression distance - $10.0 \mathrm{~mm}$ 
Return distance - $20 \mathrm{~mm}$

\subsubsection{Measurement of Colour Attributes}

The colour attributes of crop i.e., 'L', 'a' and 'b' were recorded using a colour reader instrument CR-10 (Konick Minolta Sensing Inc. Japan) on the surface of crop at three different locations. The total change in colour $(\Delta \mathrm{E})$ attributes over the period of storage time was calculated by the following equation [23]:

\section{See formula 2 in the supplementary files.}

where $L_{0}, a_{0}, b_{0}$ are the initial color measurements of the 0 th day and $L_{t}, a_{t}, b_{t}$ are the color measurements at a prespecified time.

\subsubsection{Overall Acceptability of the Crop}

The sensory evaluation scale for rating the overall acceptability of the stored fruits and vegetables was developed on the basis of three main parameters, i.e., appearance, colour and texture. The sensory assessment for the samples were carried out by a five member trained panel, and these quality parameters of the samples were examined by using the rating scales proposed respectively by [25]. All the samples were arranged for visual quality evaluation and samples were ranked using nine point heddonic scale: 1-dislike extremely, 2-dislike very much, 3-dislike moderately, 4-dislike slightly, 5-neither dislike nor like, 6-like slightly, 7-like moderately, 8-like very much, 9-like extremely. At the end of session, panelists were asked to report their purchase intention on following scales: 9-definitely would buy, 7probably would buy, 5-may be/may be not, 3-probably would not buy and 1-definitely would not buy [26].

\subsection{Statistical Analysis}

All the experimentation was carried out in triplicate. The data obtained during quality evaluation of fruits and vegetables was subjected to two way analysis of variance (ANOVA) using SAS statistical software (SAS 9.4). Significance differences between average rates of change of quality parameters of crop stored in thermoelectric refrigeration, vapour compression refrigeration and ambient storage conditions were resolved by Tukey's test for comparison. A $p<0.05$ value indicated significance of difference of effect of storage condition and crop species on quality parameters during storage.

\section{Results And Discussion}

\subsection{Effect of Storage System on Physiological Loss in Weight (PLW)}

The PLW is the key element for shelf life and post-harvest quality evaluation of fruits and vegetables. It is the measure of loss in weight of crop over a period of time due to physico-chemical changes in the crop. The loss in weight of fruits and vegetables stored in LCTR, VCR, and ambient conditions was observed. It 
was observed that the weight loss of all four crop species, i.e., bitter gourd, okra, mango, and papaya was increased with an increase in storage period irrespective of storage condition and crop species. Among the vegetables, crops stored in the VCR witnessed the least change in PLW of $13.58 \%$ and $12.90 \%$ for bitter gourd and okra at the end of 9 and 10 days of storage respectively. Conversely, the highest PLW of $16.83 \%$ and $17.71 \%$ was recorded for crops stored in ambient storage conditions at the end of 4 and 5 days of storage period. The PLW of crop stored in LCTR lied at intermediate as $11.51 \%$ and $10.99 \%$ for bitter gourd and okra after 7 and 8 days of storage respectively. The ambient storage condition reported the highest average rate of change of PLW followed by LCTR and VCR storage for bitter gourd as well as okra. Among the fruits, the least PLW was recorded at ambient storage as $10.33 \%$ and $8.15 \%$ for mango and papaya at the end of 6 and 4 days, respectively. The highest PLW was reported in the VCR system for mango $(21.22 \%)$ and papaya (16.52\%) respectively at the end of the storage period. The LCTR system reported intermediate PLW of $12.29 \%$, and $19.17 \%$ for mango and papaya, respectively. Though the VCR system registered the highest increase in PLW, it reported the least average rate of change of PLW followed by LCTR and ambient storage for mango as well as papaya, as shown in Table 2.

Table 2. Statistical significance for interaction of storage method and crop for average daily changes in quality parameters of crop. 


\begin{tabular}{|c|c|c|c|c|c|c|}
\hline Crop & $\begin{array}{l}\text { Storage } \\
\text { Method }\end{array}$ & $\begin{array}{l}\text { Quality } \\
\text { Parameters }\end{array}$ & & & & \\
\hline PLW & Firmness & Colour Value a & $\begin{array}{l}\text { Colour Change } \\
(\Delta \mathrm{E})\end{array}$ & $\begin{array}{l}\text { Overall } \\
\text { Acceptability }\end{array}$ & & \\
\hline $\begin{array}{l}\text { Bitter } \\
\text { Gourd }\end{array}$ & LCTR & $1.643^{c b d}$ & $0.489 a b$ & $0.857^{c d}$ & $\begin{array}{l}2.917 \\
b c\end{array}$ & $\begin{array}{l}0.57 \\
c d\end{array}$ \\
\hline VCR & 1.507 cde & $0.330^{b}$ & $0.603^{d}$ & $2.647^{b c d}$ & $\begin{array}{l}0.40 \\
\text { ef }\end{array}$ & \\
\hline Ambient & $3.367^{a}$ & $2.000^{a}$ & $1.753^{b}$ & $5.490^{a}$ & $1.42^{a}$ & \\
\hline Okra & LCTR & $1.377^{\text {cde }}$ & $0.080^{b}$ & $1.113^{\mathrm{bcd}}$ & $\begin{array}{l}1.637 \\
d\end{array}$ & $\begin{array}{l}0.46 \\
\text { de }\end{array}$ \\
\hline VCR & 1.290 cde & $0.071^{b}$ & $0.983^{c d}$ & $1.383^{d}$ & $\begin{array}{l}0.37 \\
\text { ef }\end{array}$ & \\
\hline Ambient & $3.543^{a}$ & $2.000^{a}$ & $1.360 \mathrm{bc}$ & $3.697^{b}$ & $1.00^{b}$ & \\
\hline Mango & LCTR & $1.230 \mathrm{de}$ & NA & $0.803^{c d}$ & $\begin{array}{l}1.837 \\
\mathrm{~cd}\end{array}$ & $\begin{array}{l}0.40 \\
\text { ef }\end{array}$ \\
\hline VCR & $1.033^{\mathrm{e}}$ & NA & $0.623^{d}$ & $1.373^{d}$ & $0.25^{f}$ & \\
\hline Ambient & $1.720 \mathrm{bc}$ & NA & $1.183^{b c d}$ & $3.647^{b}$ & $0.67^{c}$ & \\
\hline Papaya & LCTR & 1.473 cde & NA & $0.777^{\mathrm{cd}}$ & $\begin{array}{l}1.823 \\
\mathrm{~cd}\end{array}$ & $\begin{array}{l}0.34 \\
\text { ef }\end{array}$ \\
\hline VCR & 1.323 cde & NA & $0.617^{d}$ & $1.370^{d}$ & $0.25^{f}$ & \\
\hline Ambient & $2.037^{b}$ & NA & $2.463^{a}$ & $5.150^{a}$ & $1.00^{b}$ & \\
\hline
\end{tabular}

*Same lowercase superscript letters (a-f) in column indicate no statistical significant difference whereas different combinations of a-f letter indicates significant statistical difference among stored crop and storage system.

An analysis of variance (ANOVA) for the average change of PLW indicated a significant effect of the different storage systems $(p<0.0001)$ as well as crop species $(p<0.0001)$. As shown in Figure 4 , the diffogram generated from the ANOVA indicated that no significant difference in the PLW value existed between the LCTR and VCR system, as the red line of the LCTR and VCR passes through the confidence interval, whereas, the ambient storage condition was significantly different from the LCTR and VCR systems. Similarly, the red line of bitter gourd and okra passing through the confidence interval indicated that no significant difference existed among the vegetables. However, significant differences existed among fruits, i.e., mango and papaya as well as between fruits and vegetables. It was also observed that 
interaction of the storage system and crop species had a significant effect $(p<0.0001)$ on physiological loss in the weight of crop (Table 2).

The overall increase in the PLW with the increase of storage duration was attributed due to respiration by the crop species, transpiration of water through the tissues, and other physico-chemical changes taking place in the crop $[27,28]$. As the fresh produce continues to respire during storage, carbon loss through the gas exchange during the respiration process causes a reduction in the weight of the crop while transpiration of water vapour from the surface of the crop was another contributor for PLW from the crop [29]. The metabolic activities of the fruits and vegetables continue after the harvest of the crop. The difference in water vapour pressure at the surface of the product and the environment causes moisture loss from the product which leads to a reduction in the weight of the product [30]. Hence the physiological loss in the weight of the crop is equivalent to the loss of water vapour from the surface of the crop and loss of carbon during respiration of the crop [29]. Similar results were reported by [31] for bitter gourd wrapped with LDPE packaging and stored at different temperatures.

\subsection{Effect of Storage Condition on Firmness}

The texture of vegetables has been considered as an index for consumer acceptability of commodity as it determines the quality and freshness of the crop. The firmness of the fruits and vegetables depends upon the physical anatomy of the tissue, i.e., cell size and shape, strength, the way in which cells bind together to form a tissue and wall thickness [32,33].

It was observed that the firmness of bitter gourd and okra was decreased with an increase of storage duration irrespective of the storage system. The highest loss in firmness of $41.2 \%$ and $47.8 \%$ were registered under the ambient storage system at the end of 4 and 5 days of storage for bitter gourd and okra, respectively. On the contrary, the highest retention of firmness was recorded for crops stored in the VCR system which was reduced by $52.7 \%$ and $46.3 \%$ for bitter gourd and okra at the end of 9 and 10 days of storage life, respectively. The firmness retention capacity of the LCTR system was comparable with the VCR system at $58.7 \%$ and $41.9 \%$ at the end of 7 and 8 days of storage for bitter gourd and okra, respectively.

An analysis of variance (ANOVA) for the average rate of firmness reduction indicated the significant effect of the different storage systems $(p=0.0002)$, whereas, a nonsignificant effect existed between bitter gourd and okra $(p=0.430)$ at a $5 \%$ level of significance. The diffogram generated from ANOVA as shown in Figure 5 indicated that no significant difference exists between LCTR and VCR, however, the ambient storage system was significantly different from LCTR and VCR. It was also revealed from the diffogram that average daily firmness reduction was the same for bitter gourd and okra irrespective of the storage system as seen by the interaction line passing through the region of the confidence interval. It was also observed that the interaction of the storage system and crop had no significant effect $(p=$ 0.828) on the firmness of the crop, as presented in Table 2. 
The decreasing trend of firmness with the increasing storage period of the crop was attributed due to the mechanism of cell wall digestion by pectinesterase, polygalacturonase and other enzymes. The process of the disruption of the tissue and cell wall accelerates in crops stored at higher temperatures [34]. The study conducted by [11] for the storage of cucumber at different temperatures and relative humidity also showed the negative effect of storage duration on the firmness of cucumbers. The maximum retention of firmness of the crop stored at lower temperature was attributed due to the presence of higher relative humidity which prevents the transmission of moisture and ultimately shrinkage of the crop. [35] explained the mechanism of firmness retention at a lower temperature as a halt of enzyme activities, delayed oxidative decomposition and inhibition of expression of many genes during cold storage. The reduction in firmness at higher storage temperatures was due to the breakdown of insoluble protopectin into soluble pectin and cellular disintegration [36]. [31] also reported a loss in firmness of bitter gourd during storage due to shrinkage of the product caused by water loss.

\subsection{Effect of Storage Condition on Colour}

Colour is one of the major visual attributes of fruits and vegetables. It is the colour of the commodity that comes into the first appearance and influences consumer's attraction towards crops. The surface colour of okra, bitter gourd, mango and papaya was measured for determination of changes in colour due to physiochemical reactions and ripening of fruits and vegetables during storage. For the determination of the effect of storage conditions and storage period on colour of the crop, colour attributes i.e., 'a' and colour change ' $\Delta \mathrm{E}^{\prime}$ ' were determined and explained under the following sub-headings.

\subsubsection{Effect of Storage Condition on Colour Value 'a'}

The colour value ' $a$ ' varies from negative to positive representing the greenness to redness of the crop. The greenish appearance of fruits and vegetables is the indicator of chlorophyll content in crops (Barrett et al. 2010).

In the present study, '-a' representing the green value of all the crops deteriorated during the storage period irrespective of storage conditions. Among the vegetables, a decrease of the '-a' value was more pronounced in ambient conditions for bitter gourd (43.33\%) and okra (48.53\%) and least in VCR for bitter gourd $(24.17 \%)$ and okra (28.67\%). The greenness retention capacity of LCTR lied intermediate to that of ambient and VCR storage. The (-a) value of crop stored in the LCTR declined by $38.33 \%$ and $31.62 \%$ for bitter gourd and okra during the storage period, respectively. Similarly, among the fruits, the decrease in lightness was more pronounced for fruits stored in ambient storage for mango (50.00\%) and papaya $(65.77 \%)$ at the end of four and six days of storage, respectively, whereas, the least change was recorded in VCR storage of mango (47.52\%) and papaya (64.43\%) at the end of 16 days of storage. The LCTR storage system reported an intermediate effect of greenness reduction, recording $47.30 \%$ and $64.47 \%$ reduction for mango and papaya at the end of 10 and 13 days of storage, respectively.

An analysis of variance (ANOVA) for average daily change of colour value 'a' revealed that colour value 'a' was significantly influenced by storage condition $(p<0.0001)$ as well as crop species $(p=0.0091)$ at a 
$5 \%$ level of significance. The diffogram (Figure 6) generated from ANOVA also indicated that no significant difference of average daily change of colour value 'a' exist among LCTR and VCR storage conditions, whereas, ambient storage condition was significantly different from LCTR and VCR storage. The diffogram also revealed that the average rate of reduction in greenness for mango was significantly different from that of papaya, whereas, no significant difference exists between mango, bitter gourd and okra. It was also observed from Table 2 that the interaction of storage condition and crop had a significant effect $(p<0.0001)$ on the rate of decrease in lightness value.

The reduction of '-a' value was in accordance with [37]. It was also reported that the storage of green crops at higher temperatures results in a rapid transition of crop colour from green to reddish. The change in colour of the crop was due to the ripening of the crop. It was also reported that storage of the green crop at higher temperature results in rapid transition of crop colour from green to yellowish. The increase in yellowness during the storage period was might be due to the breakdown of chlorophyll as well as an increase in carotenoid inside the pulp during physico-chemical changes taking place during ripening which leads to the turning of the green colour of the crop from light green or dark green to yellowish or yellowish-red [38].

\subsubsection{Effect of Storage Condition on Overall Colour Change}

The colour change value $(\Delta \mathrm{E})$ represents an overall change in the colour of the crop during the storage period compared to the initial colour of that crop. In the present study, the increasing trend of the colour change value was observed during the storage period irrespective of storage condition and crop species.

Among the vegetables, ambient storage condition had a remarkable effect on overall colour change $(\Delta \mathrm{E})$ for bitter gourd (21.97) and okra (18.48), whereas, least colour change was recorded in VCR storage for bitter gourd (15.02) and okra (13.81) at the end of respective storage duration. The colour change for crops stored in the LCTR system was intermediate of ambient and VCR storage. The colour change for LCTR storage was 14.04 and 11.46 for bitter gourd and okra at the end of the storage period. Similarly, among the fruits, ambient storage conditions reported the highest increase in colour value for both fruits which was reported to be 21.89 and 20.60 for mango and papaya respectively at the end of their respective storage period. The least colour change was recorded for fruits stored in VCR storage conditions, registering 18.42 and 21.77 for mango and papaya respectively. The LCTR storage system reported intermediate effect on colour change, recording 16.41 and 23.68 for mango and papaya respectively at the end storage duration.

It was also revealed from an analysis of variance (ANOVA) for an average rate of change of colour $(\triangle E)$ that storage condition, as well as crop species, had a significant effect $(p<0.0001)$ on colour change at $1 \%$ level of significance. The diffogram (Figure 7) generated from ANOVA indicated that no significant difference of average daily change of colour change exist among LCTR and VCR storage condition, whereas, ambient storage condition was significantly different from LCTR and VCR storage. The diffogram also revealed that the average daily change of colour change for bitter gourd was significantly different from all the other crops, while no significant difference exists among okra, mango, and papaya. 
It was also be observed from Table 2 that the interaction of storage condition and the crop had a significant effect $(p<0.0489)$ on the rate of increase in colour change value.

The change in colour during storage of fruit and vegetables was also reported by $[39,40,28]$. It was also reported that the storage of green crops at higher temperatures results in a rapid transition of crop colour from green to yellowish. The increase in yellowness during the storage period was might be due to the breakdown of chlorophyll as well as an increase in carotenoid inside the pulp during physico-chemical changes taking place during ripening which leads to the turning of the green colour of the crop from light green or dark green to yellowish or yellowish-red (38). The change in colour from green to yellow of mango and papaya was due to chlorophyll degradation and carotenoid synthesis during the maturity of fruits.

\subsection{Effect of Storage Condition on Overall Acceptability}

The overall acceptability of fruits and vegetables is a vital parameter as it directly determines the consumer's perception about the quality and willingness to purchase of crop. The acceptability of the crop was evaluated in terms of colour changes, visual spoilage, softness and ripeness.

It was observed that the overall acceptability showed a decreasing trend during storage irrespective of storage conditions and crop species. The changes in visual appearance of bitter gourd, okra, mango and papaya during the storage period have been presented in Figures 8, 9, 10 and 11, respectively. Among the vegetables, the highest reduction in overall acceptability was witnessed for crops stored at ambient storage conditions which recorded decreases of acceptability from 9.0 to 3.3 and from 9.0 to 4.0 at the end of 4 and 5 days of storage for bitter gourd and okra. Conversely, crop stored in VCR was acceptable for a longer duration which decreased from 9.0 to 5.3 and from 9.0 to 5.3 for bitter gourd and okra for the respective storage duration. The acceptability of crops stored in LCTR was intermediate, which decreased from 9.0 to 5.0 and 9.0 to 5.3 for bitter gourd and okra, respectively. Similarly, among the fruits, the ambient storage condition reported the highest decrease in the average acceptability for both fruits which decreased from 9.0 to 5.0 and from 9.0 to 5.0 for mango and papaya respectively during the storage period. The least decrease in acceptability was recorded for fruits stored in VCR storage conditions, registering an increase from 9.0 to 5.0 and from 9.0 to 5.0 for mango and papaya respectively. The LCTR storage system reported an intermediate effect on acceptability, recording a decrease from 9.0 to 5.0 and from 9.0 to 4.7 for mango and papaya respectively during storage duration.

An analysis of variance (ANOVA) for the average rate of change of overall acceptability revealed that acceptability was significantly influenced by storage condition $(p<0.0001)$ as well as crop species $(p<$ 0.0001 ) at $1 \%$ level of significance. The diffogram (Figure 12) generated from the ANOVA also indicated that there was significant difference among LCTR, VCR and ambient storage conditions for the rate of change of the overall acceptability of crop. The diffogram also revealed that significant differences exists among bitter gourd, okra, mango and papaya for the average rate of change of acceptability. It was also observed that the interaction of storage condition and crop species had a significant effect $(p<0.0001)$ 
on rate of decrease of acceptability. Table 2 indicated the variation in the average rate of decrease in acceptability for the interaction of storage conditions and crop species.

An analysis of variance (ANOVA) for the average rate of change of overall acceptability revealed that acceptability was significantly influenced by storage condition $(p<0.0001)$ as well as crop species $(p<$ 0.0001 ) at a $1 \%$ level of significance. The diffogram (Figure 12) generated from the ANOVA also indicated that there was a significant difference among LCTR, VCR and ambient storage conditions for the rate of change of the overall acceptability of the crop. The diffogram also revealed that significant differences exist among bitter gourd, okra, mango and papaya for the average rate of change of acceptability. It was also observed that the interaction of storage condition and crop species had a significant effect $(\mathrm{p}<$ 0.0001) on the rate of decrease of acceptability. Table 2 indicated the variation in the average rate of decrease in acceptability for the interaction of storage conditions and crop species.

\section{Conclusions}

An eco-friendly thermoelectric refrigerator of 100 liter capacity based on the Peltier effect has been developed and the performance was evaluated for keeping the quality of fruits and vegetables as compared to the same stored at ambient temperature. The thermoelectric refrigerator can be operated at the temperature range of $15-17{ }^{\circ} \mathrm{C}$ and relative humidity of $80-90 \%$, which was approaching the storage conditions required for most summer fruits and vegetables. The thermoelectric refrigeration facilitated impressive results for the quality retention of fruits and vegetables during storage. A remarkable improvement in the shelf life of all the fruits and vegetables was reported by using thermoelectric refrigeration in comparison to the ambient storage system. The shelf life of bitter gourd, okra, mango and papaya stored in a thermoelectric refrigeration system was increased up to 7, 810 and 12 days, respectively. As the statistical analysis indicated no significant difference in the quality attributes of a commodity stored in the vapour compression refrigeration and thermoelectric refrigeration systems, it was concluded that adequate scope exists for the utilization of the developed thermoelectric refrigeration system for the cold storage of fruits and vegetables. As there is a lack of scientific cold storage infrastructure for maintaining the quality of fruits and vegetables during transportation in rural areas and being an eco-friendly and sustainable refrigeration technology, the thermoelectric refrigerator is not only helpful for generating carbon credits but also facilitates cold chain management of perishable crops. Effective cold chain techniques at the community level act as a link between the agriculture field and end consumers by stretching the marketable time of the perishable products. The producers can also meet the demands and have a higher share of profit with reduced loss. Farmers and owners of the product can reach newer markets to realize greater circular economic value.

\section{Abbreviations}




\begin{tabular}{|llll|}
\hline$\%$ & $:$ percentage & $\mathrm{min}$ & $:$ minutes \\
\hline${ }^{\circ} \mathrm{C}$ & $:$ Celsius & $\mathrm{ml}$ & $:$ millilitre \\
\hline$\Delta \mathrm{E}$ & $:$ Total change in colour & $\mathrm{mm}$ & $:$ millimetre \\
\hline Anon & $:$ Anonymous & $\mathrm{N}$ & $:$ Newton \\
\hline $\mathrm{cm}$ & $:$ centimetre & $\mathrm{RH}$ & $:$ Relative Humidity \\
\hline $\mathrm{COP}$ & $:$ Coefficient of Performance & $\mathrm{S}$ & $:$ second \\
\hline $\mathrm{D} . \mathrm{C}$. & $:$ Direct Current & $\mathrm{V}$ & $:$ Voltage (Volt) \\
\hline $\mathrm{g}$ & $:$ gram & $\mathrm{W} . \mathrm{b}$. & $:$ wet basis \\
\hline $\mathrm{h}$ & $:$ hour & $\mathrm{CFC}:$ Chlorofluorocarbons \\
\hline $\mathrm{I}$ & $:$ Current & HFC : Hydrofluorocarbon \\
\hline $\mathrm{A}$ & $:$ Ampere & HCFC : Hydrochlorofluorocarbons \\
\hline $\mathrm{J}$ & $:$ Joule & UNEP : United Nations Environment Programme \\
\hline${ }^{\mathrm{o}}$ & $:$ kelvin & FAO : Food and Agriculture Organisation \\
\hline $\mathrm{kg}$ & $:$ kilogram & PLW : Physiological Loss in Weight \\
\hline $\mathrm{kg} \mathrm{m}{ }^{-3}$ & $:$ kilogram per cubic meter & LCTR : Liquid Cooled Thermoelectric Refrigerator \\
\hline $\mathrm{m}$ & $:$ meter & VCR : Vapour Compression Refrigerator \\
\hline $\mathrm{mg}$ & $:$ milligram & INR : Indian Rupee \\
\hline
\end{tabular}

\section{References}

1. Keating, A.; Herrero, M.; Carberry, P.S.; Gardner, J.; Cole, M.B. Food wedges: Framing the global food demand and supply challenge towards 2050. Glob. Food Secur. 2014, 3, 125-132.

2. Murthy, S.; Gajanana, T.M.; Sudha, M.; Dakshinamoorthy, V. Marketing and postharvest losses in fruits: Its implications on availability and economy. Indian J. Agric. Econ. 2009, 64, 259-275.

3. Global Food Losses and Food Waste. Extent, Causes and Prevention. 2011. Available online: http://www.fao.org/docrep/014/mb060e/mb060e00.htm (accessed on 20 December 2019).

4. Sparks, A. Postharvest handling systems for fresh fruits and vegetables in sub-Saharan Africa and potential enhancement by the Aid for trade initiative. MS, University of Georgia, Athens, Georgia, 2013.

5. Wastage of Agricultural Produce. Press Information Bureau (PIB), 2016 Ministry of Food Processing Industries, Government of India. (Published on 2016). 
6. Gardas, B.B.; Raut, R.D.; Narkhede, B. Modeling causal factors of post-harvesting losses in vegetable and fruit supply chain: An Indian perspective. Renew. Sustain. Energy Rev. 2017, 80, 1355-1371.

7. James, J.; James, C. Chilling and Freezing of Foods. Clark S, Jung S, and Lamsal, B. Food Processing: Principles and Applications, 2nd ed.; John Wiley \& Sons, Ltd.: Hoboken, NJ, USA, 2014.

8. Tassou, ; Lewis, J.; Ge, Y.; Hadawey, A.; Chaer, I. A review of emerging technologies for food refrigeration applications. Appl. Therm. Eng. 2010, 30, 263-276.

9. Kaur, ; Rai, D.R.; Paul, S. Quality changes in fresh-cut spinach (spinacia oleracea) under modified atmospheres with perforations. J. Food Qual. 2011, 34, 10-18.

10. Kandale, U. Optimization of Modified Atmosphere Packaging for Cucumber (Cucumis sativus L.). Master's Thesis, Punjab Agricultural University, Ludhiana, India, 2013.

11. Manjunatha, ; Anurag, R.K. Effect of modified atmosphere packaging and storage conditions on quality characteristics of cucumber. J. Food Sci. Technol. 2014, 51, 3470-3475.

12. Cainelli, ; Ruperti, B. Biochemistry and molecular biology in fruits during cold storage. Annu. Plant Rev. 2019, 2, 1-29.

13. Mudgil, ; Barak, S. Functional Foods: Sources and Health Benefits; Scientific Publishers: Jodhapur, India, 2017.

14. Mudgil, ; Barak, S. Beverages: Processing and Technology, Scientific Publishers: Jodhapur, India, 2018.

15. Handbook for International Treaties for Protection of the Ozone Layers, 6th ed.; United Nation Environment Program (UNEP): Nairobi, Kenya, 2003.

16. Low-GWP Alternatives in Commercial Refrigeration: Propane, $\mathrm{CO}_{2}$ and HFO Case Studies. UNEP, Division of Technology, Industry and Economics (DTIE) and Climate and Air Coalition to Reduce Short-lived Climate Pollutants (CCAC) [Online]. 2014. Available online: http://www.ccacoalition.org (accessed on 4 July 2017).

17. Food and Agriculture Organization (FAO) United Nations, Rome. 2016.

18. He, R.; Zhong, H.Y.; Cai, Y.; Liu, D.; Zhao, F.Y. Theoretical and experimental investigations of thermoelectric refrigeration box used for medical service. Procedia Eng. 2017, 205, 1215-1222.

19. Soylemez, ; Alpman, E.; Onat, A.; Yukselenturk, Y.; Hartomaciogulu, S. Numerical (CFD) and experimental analysis of hybrid household refrigerator including thermoelectric and vapour compression cooling systems. Int. J. Refrig. 2019, doi:10.1016/j.ijrefrig.2019.01.007.

20. Wang, ; Wang, Q.; Xu, J. Performance analysis of two-stage TECs (thermoelectric coolers) using a three-dimensional heat-electricity coupled model. Energy 2014, 65, 419-429.

21. Riffat, B.; Ma, X.L. Thermoelectrics: A review of resent and potential applications. Appl. Therm. Eng. 2003, 23, 913-935.

22. Akinyemi, O.; Simolowo, O.E. A mobile tropical cooling system design using a thermoelectric module. Trans. Mach. Learn. Artif. Intell. 2017, 5, 1-12. 
23. Tirkey, ; Pal, U.S.; Bal, L.M.; Sahoo, N.R.; Bakhara, C.K.; Panda, M.K. Evaluation of physico-chemical changes of fresh-cut unripe papaya during storage. Food Packag. Shelf Life 2014, 1, 190-197.

24. Dhall, K.; Sharma, S.R.; Mahajan, B.V.C. Development of post-harvest protocol of okra for export marketing. J. Food Sci. Technol. 2014, 51, 1622-1625.

25. Bari, L.; Nakauma, M.; Todoriki, S.; Juneja, V.K.; Isshiki, K.; Kawamoto, S. Effectiveness of irradiation treatments in inactivating listeria monocytogenes on fresh vegetables at refrigeration temperature. $J$. Food Prot. 2005, 68, 318-323.

26. Fan, ; Guan, W.; Sokorai, K.J.B. Quality of fresh-cut Iceberg lettuce and spinach irradiated at doses up to 4 kGy. Radiat. Phys. Chem. 2012, 81, 1071-1075.

27. Faasema, ; Alakali, J.S.; Abu, J.O. Effect of storage temperature on 1-methylcyclopropene treated mango (mangifera Indica) fruit varieties. J. Food Process. Preserv. 2014, 38, 289- 295.

28. Sidhu, K.; Preetinder, K.; Manpreet, S. Retention of bioactive compounds in fresh fenugreek leaves during storage under modified atmosphere packaging. Nutr. Food Sci. 2016, 46, 529-541.

29. Joshi, ; Warby, J.; Valverde, J.; Tiwari, B.; Cullen, P.J.; Frias, J.M. Impact of cold chain and product variability on quality attributes of modified atmosphere packed mushrooms (Agaricus bisporus) throughout distribution. J. Food Eng. 2018, 232, 4455.

30. Becker, R.; Fricke, B.A. Transpiration and Respiration of Fruits and Vegetables. Sci. Tech. Froid. 1998, 6, 110-121.

31. Mohammed, ; Wickham, L.D. Extension of bitter gourd (Momordica Charantza L.) Storage life through the use of reduced temperature and polyethylene wraps. J. Food Qual. 1993, 16, 371-382.

32. Barrett, D.M.; Beaulieu J.C.; Rob Shewfelt, R. Color, Flavor, texture, and nutritional quality of fresh-cut fruits and vegetables: desirable levels, instrumental and sensory measurement, and the effects of processing. Rev. Food Sci. Nutri. DOI: 10.1080/10408391003626322.

33. Mercado, J.A.; Antonio J Matas, A.J.; Sara Pose, S. Fruit and vegetable texture: Role of their cell walls. In Reference Module in Food Science. 2019. DOI: 1016/B978-0-08-100596-5.21679-X.

34. Thinh, C.; Uthaibutra, J.; Joomwong, A. Effect of storage temperatures on ripening behavior and quality change of vietnamese mango cv. Cat hoa loc. Int. J. Bio-Technol. 2013, 3, 19-30.

35. Jin, W.; Xu, C.J.; Li, X.; Zhang, B.; Wang, P.; Allan, A.C.; Chen, K.S. Expression of ROP/RAC GTPase genes in postharvest loquat fruit in association with senescence and cold regulated lignification. Postharv. Biol. Technol. 2009, 54, 9-14.

36. Cheng, ; Gong, X.; Jing, W.; Peng, Z.; Li, J. Quality change of postharvest okra at different storage temperatures. J. Food Eng. Technol. 2018, 7, 43-46.

37. Devi, S.; Mahato, D.K.; Singh, S.; Singh, S.P. Optimization of process variables for retention of functional properties of bitter melon (Momordica Charantia L.) and its shelf - life extension. Current Agric. Res. J.2019, 7(1):74-89.

38. Gowda, D.; I.N.D.; Huddar, A.G. Effect of Studies on ripening changes in mango (Mangifera Indica L.) fruits. Food Sci. Technol.2001, 38: 135-137. 
39. Ba, T.T.K Chemical treatment at preharvest and postharvest period due to improve productivity, quality, and prolongation of Cat Hoa Loc mango. Ph.D. Thesis. 2018, Can Tho University, Vietnam.

40. Tai, N.T. Applying density of fruit and ozone technology on stability quality of Cat Hoa Loc mango and Cat Chu mango fruit in postharvest. Ph.D. Thesis. 2008, Can Tho University, Vietnam.

\section{Figures}

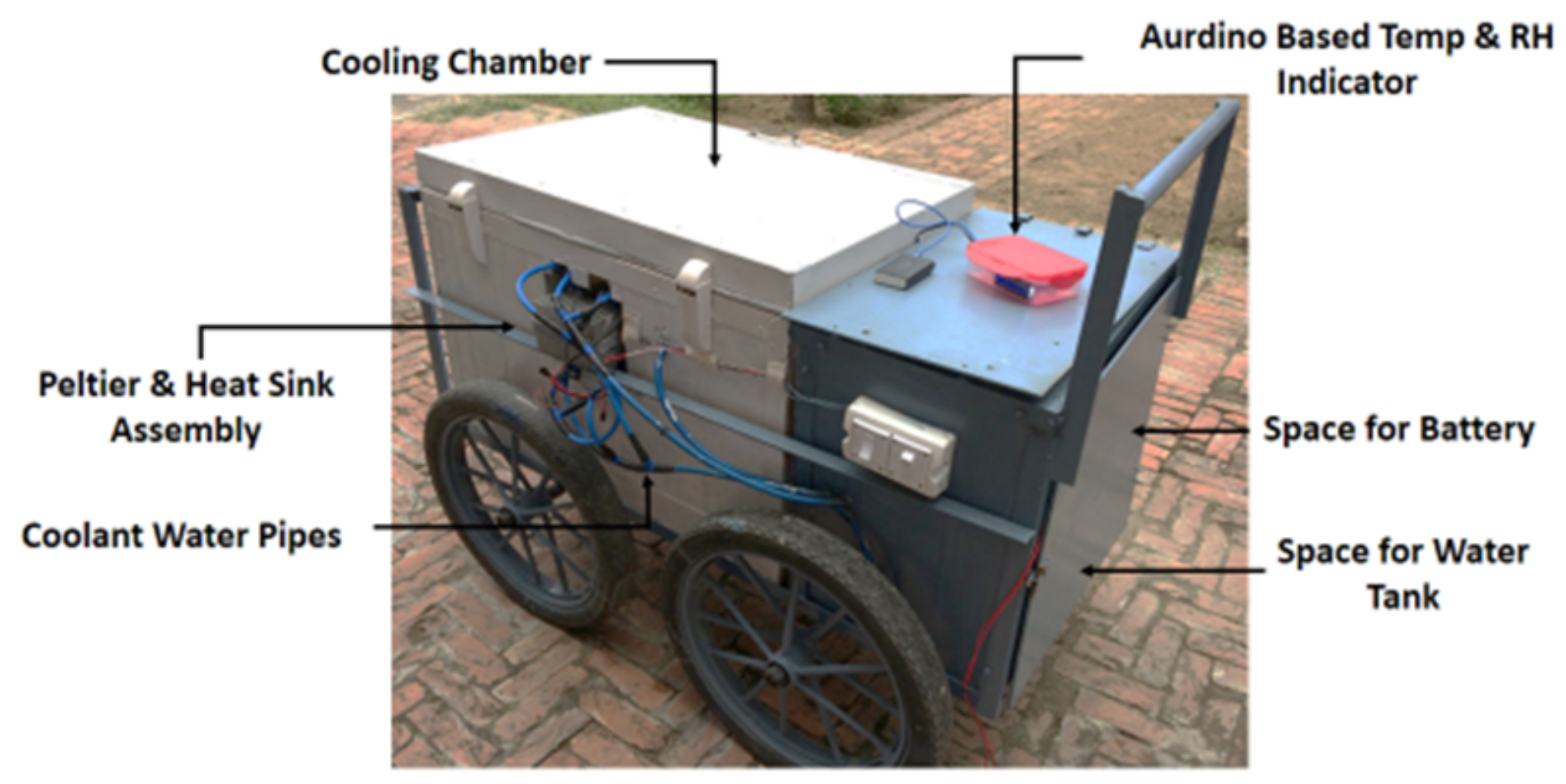

Figure 1

Complete view of developed thermoelectric refrigeration system. 


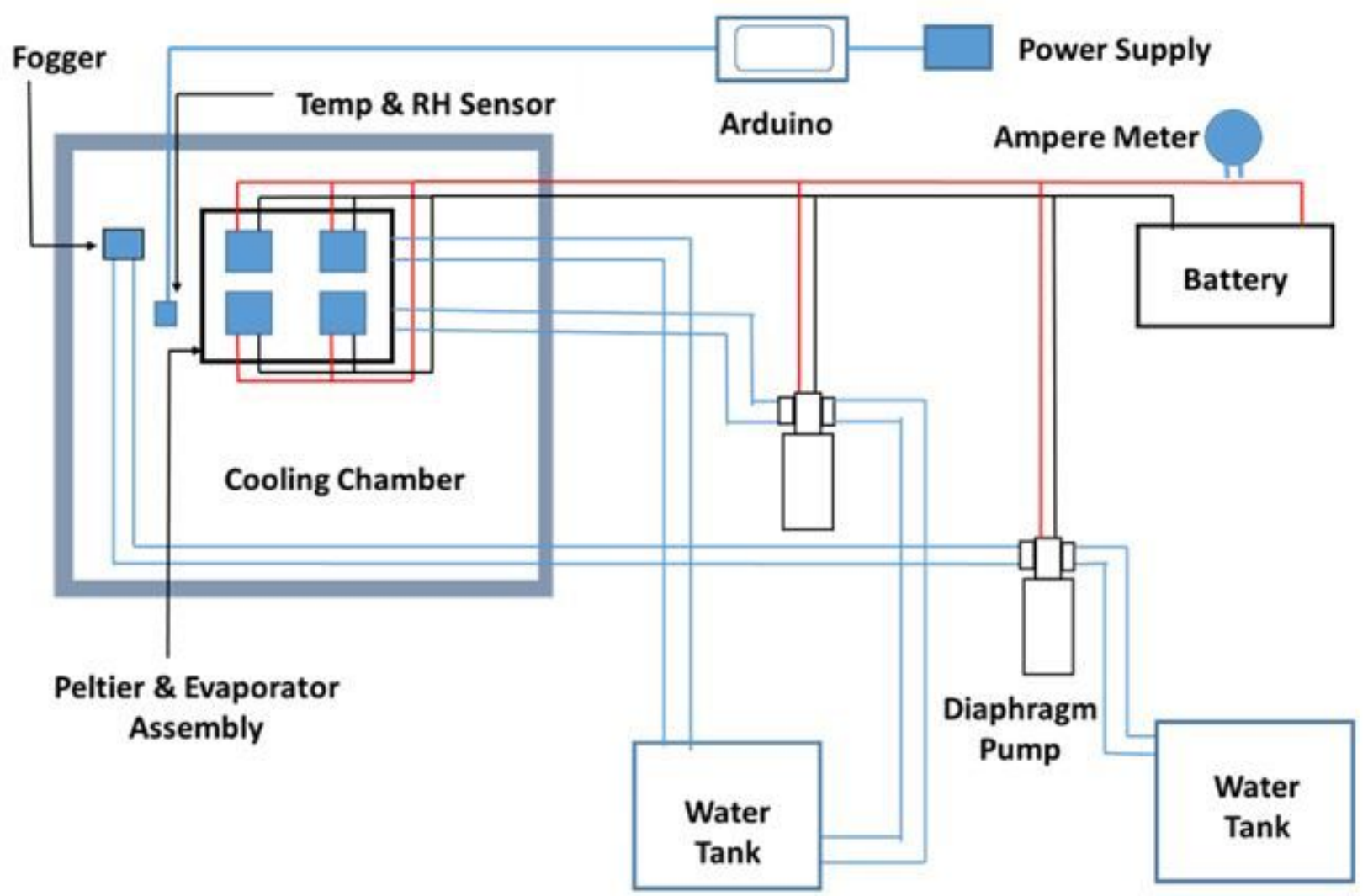

Figure 2

Schematic diagram of components assembly of thermoelectric refrigerator. 


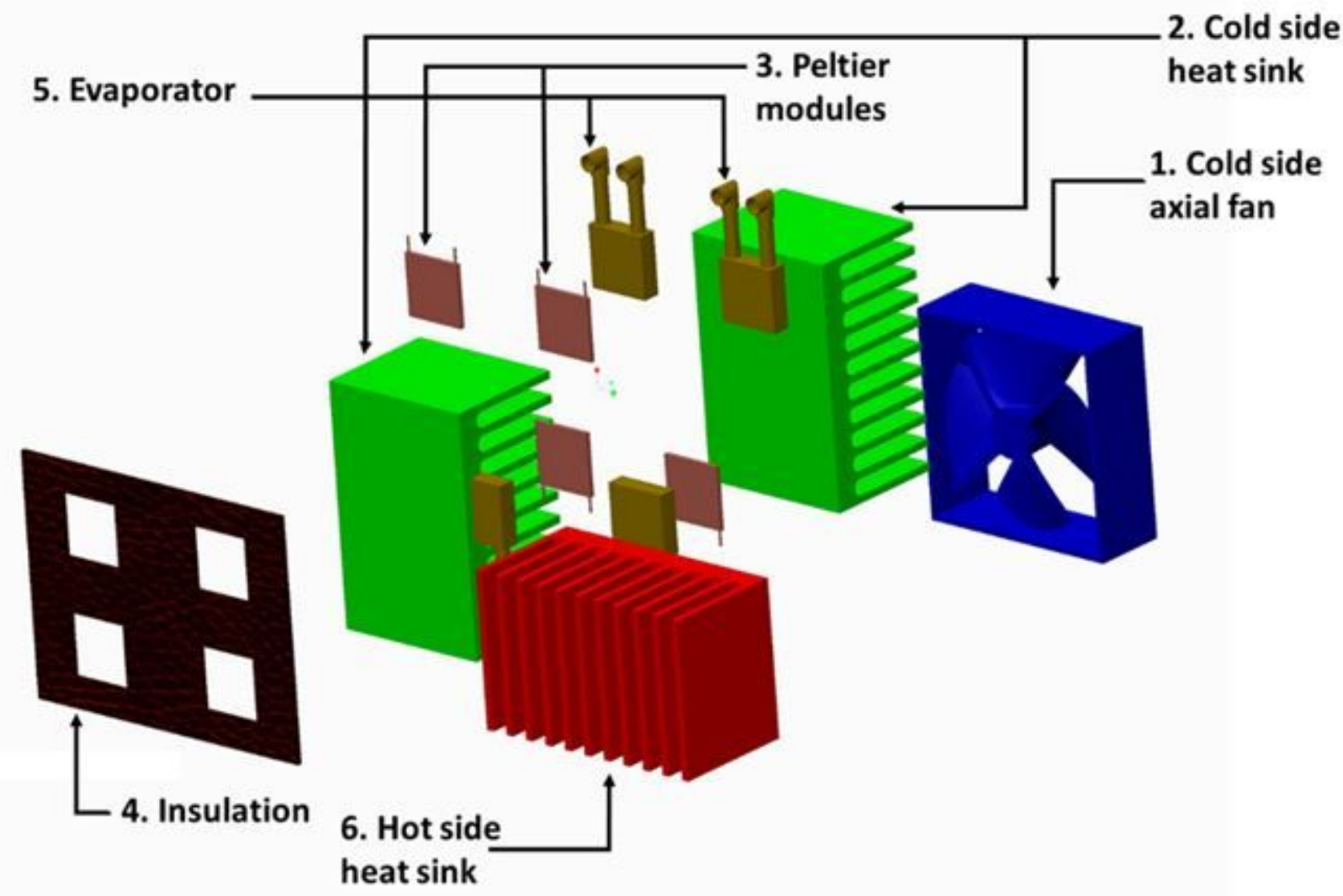

Figure 3

Expanded view of liquid cooled heat sink assembly.

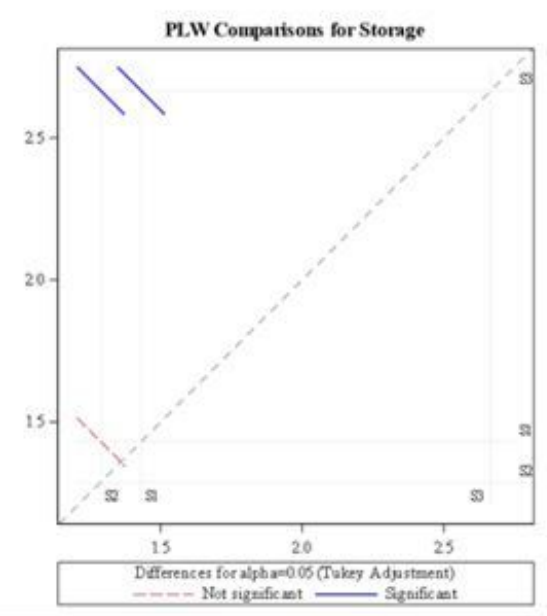

S1 - LCTR

$\mathrm{S} 2$ - VCR

S3 - Ambient storage

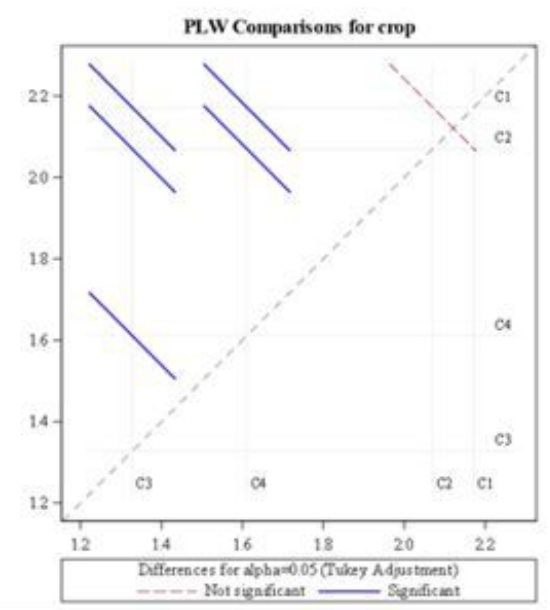

C1 - Bitter gourd

C3 - Mango

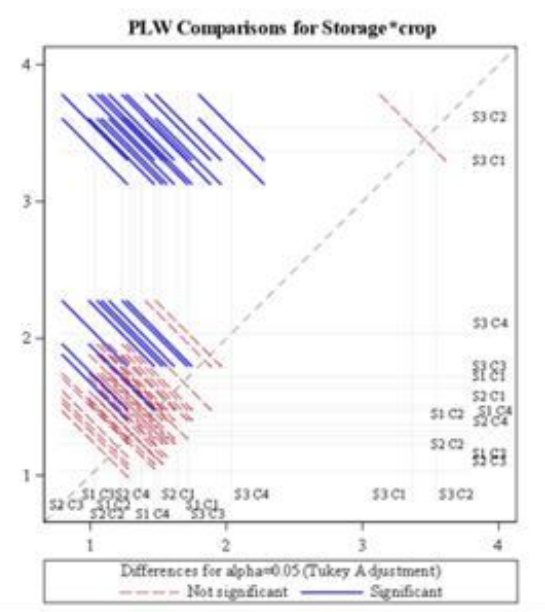

C2 - Okra

C4 - Papaya 
Figure 4

Effect of storage system on average daily change of the PLW of crop.
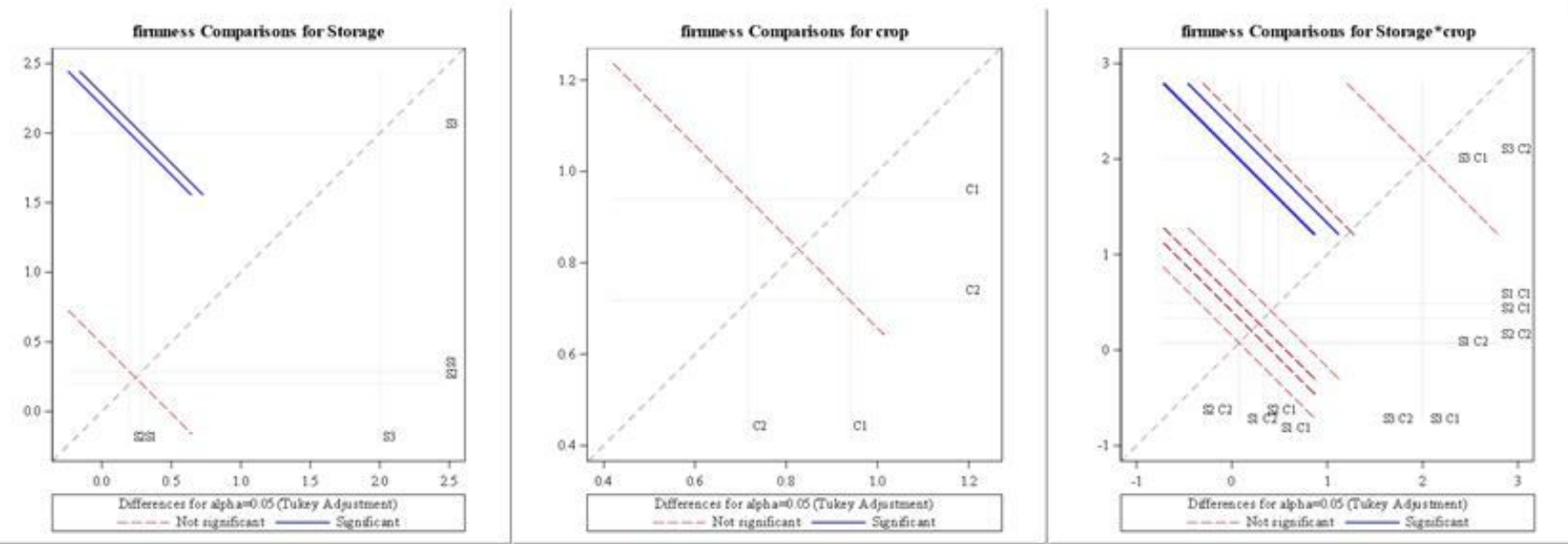

S1 - LCTR

C1 - Bitter gourd

C2 - Okra

$\mathrm{S} 2-\mathrm{VCR}$

S3 - Ambient storage

\section{Figure 5}

Effect of storage system on average daily change of firmness of crop.
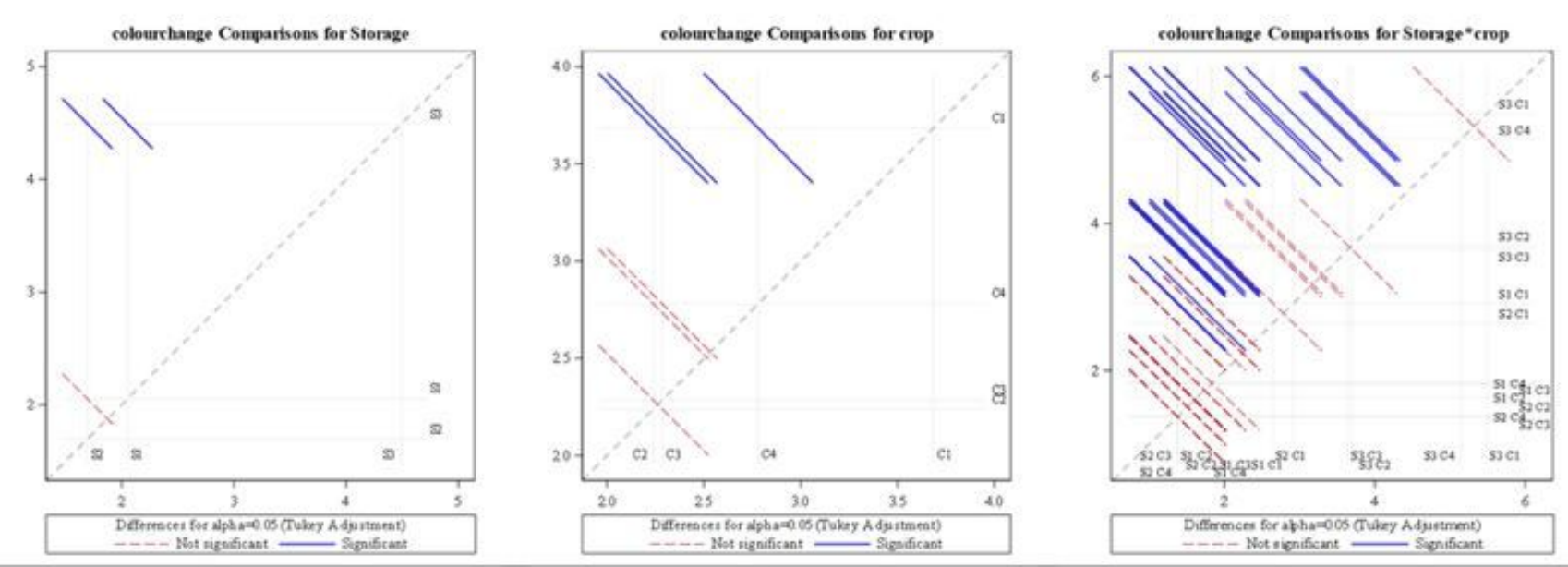
S1 - LCTR
$\mathrm{S} 2-\mathrm{VCR}$
S3 - Ambient storage

C1 - Bitter gourd

\section{C2 - Okra}

C4 - Papaya

C3-Mango

\section{Figure 6}

Effect of storage system on average daily change of colour value 'a' of crop. 

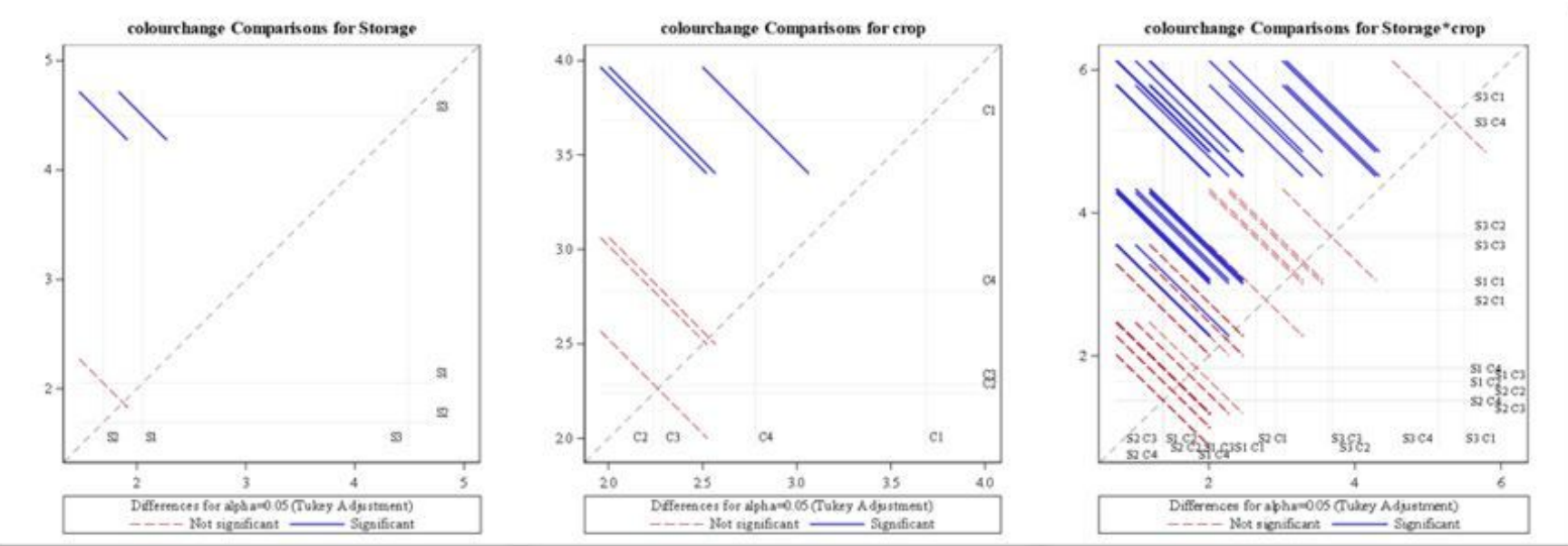

S1 - LCTR

C1 - Bitter gourd

C2 - Okra

$\mathrm{S} 2-\mathrm{VCR}$

S3 - Ambient storage

C3-Mango

C4 - Papaya

\section{Figure 7}

Effect of storage system on average daily change of colour change $(\Delta \mathrm{E})$ of crop.

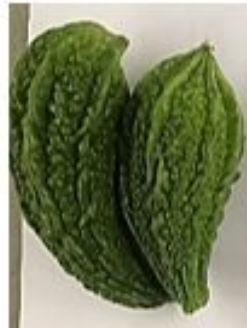

LCTR Stored

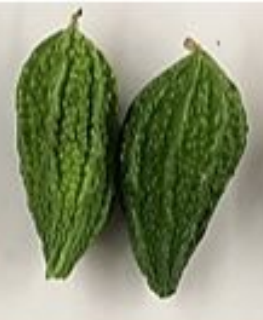

VCR Stored

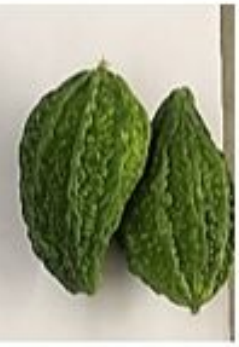

Ambient Stored

$0^{\text {th }}$ day storage

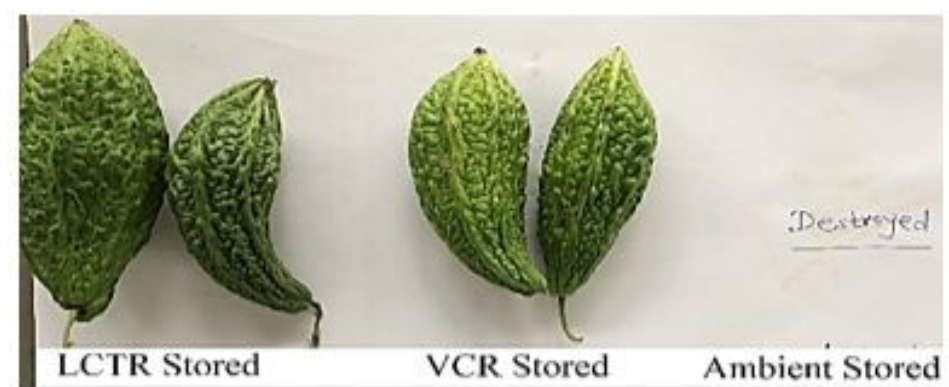

$6^{\text {th }}$ day storage

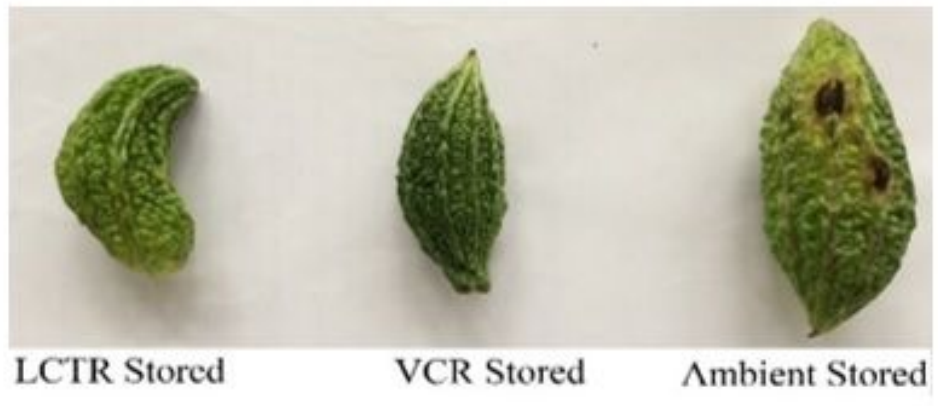

$3^{\text {rd }}$ day storage

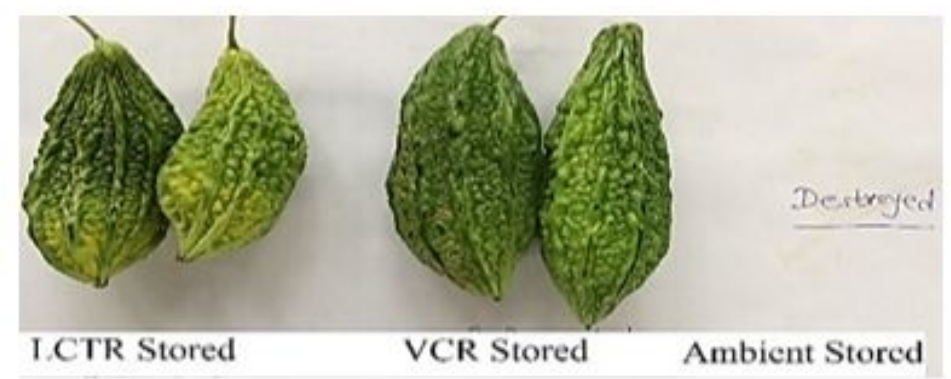

$9^{\text {th }}$ day storage

\section{Figure 8}

Effect of storage system on visual appearance of bitter gourd. 


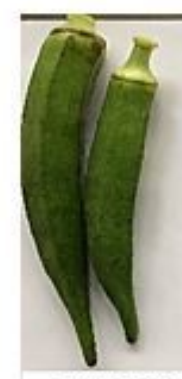

LCTR Stored

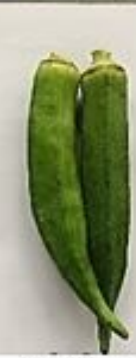

VCR Stored

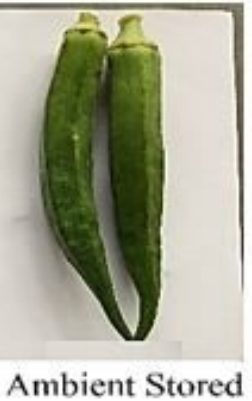

$0^{\text {th }}$ day storage

VCR Stored

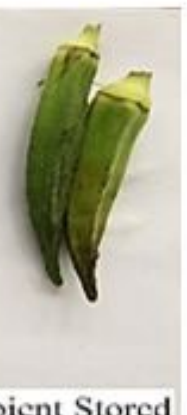

Ambient Stored

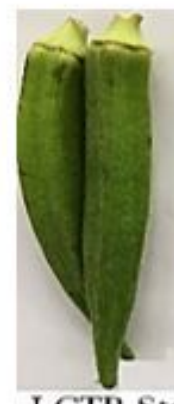

LCTR Stored

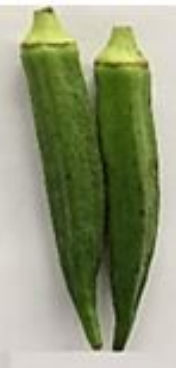

$4^{\text {th }}$ day storage

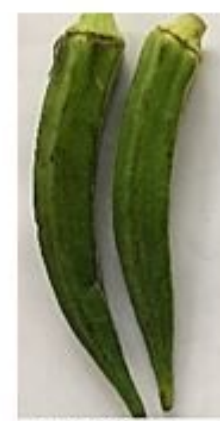

LCTR Stored

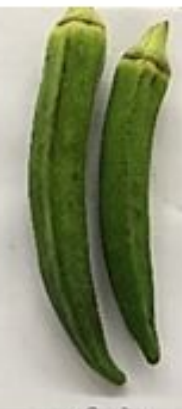

VCR Stored

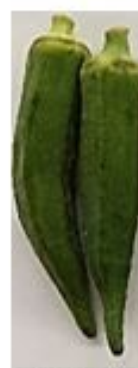

LCTR Stored

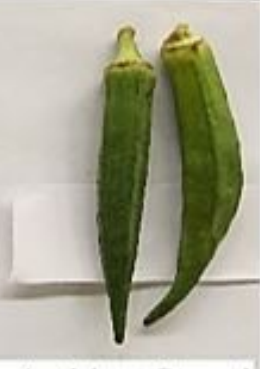

Ambient Stored

$2^{\text {nd }}$ day storage

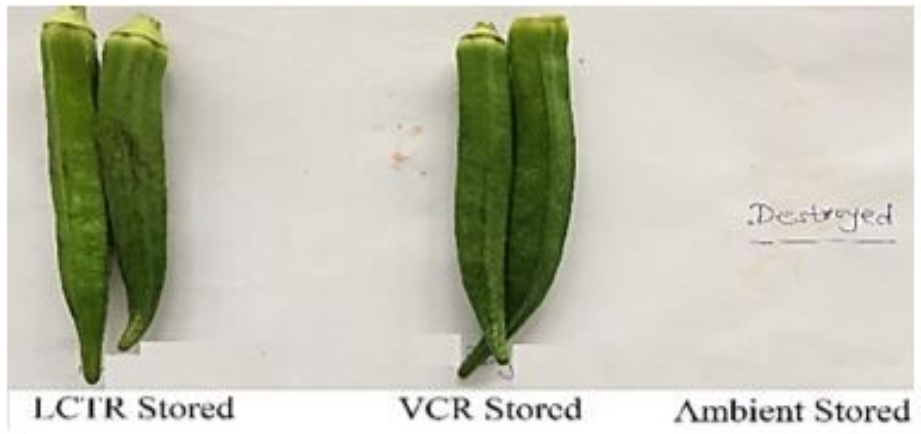

$6^{\text {th }}$ day storage

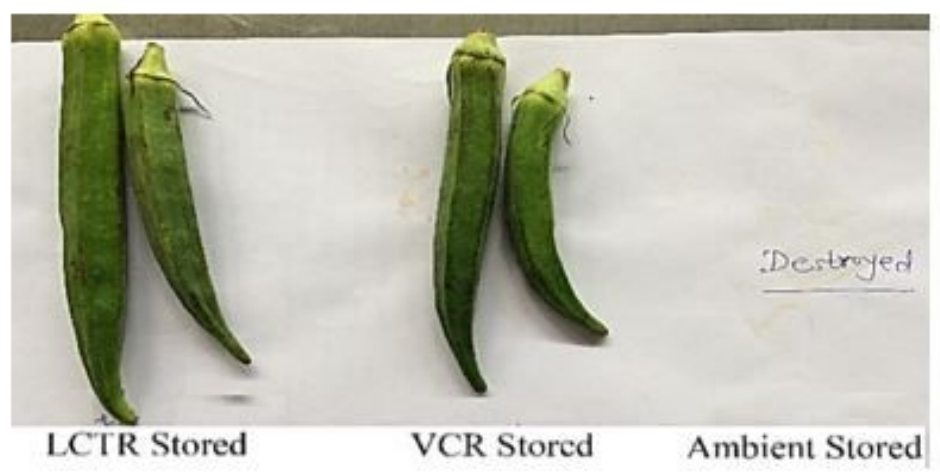

$10^{\text {th }}$ day storage

$8^{\text {th }}$ day storage

Ambient Stored

\section{Figure 9}

Effect of storage system on visual appearance of okra. 


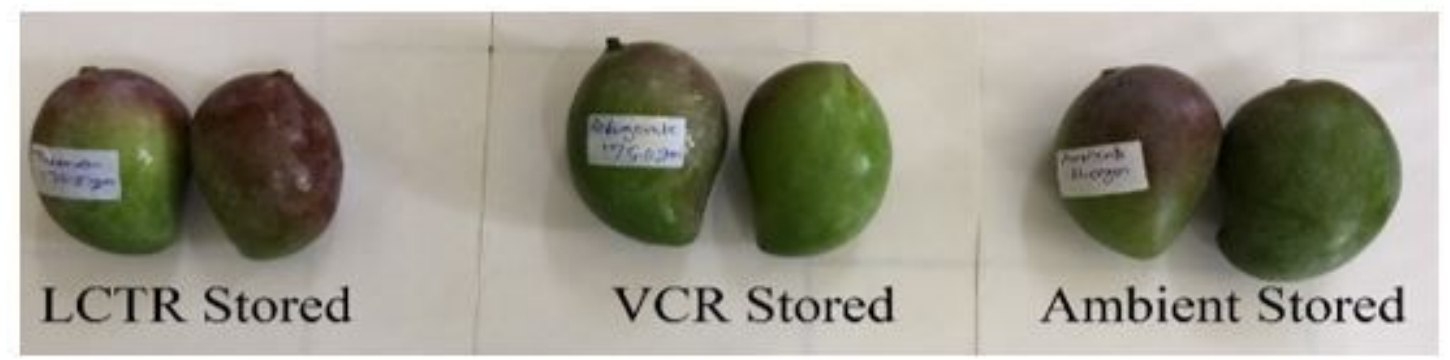

$0^{\text {th }}$ day storage

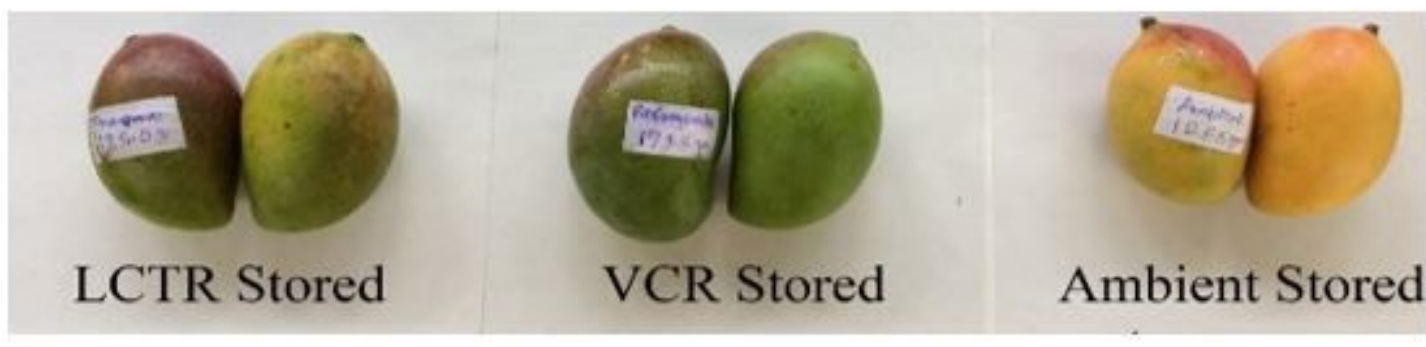

$6^{\text {th }}$ day storage
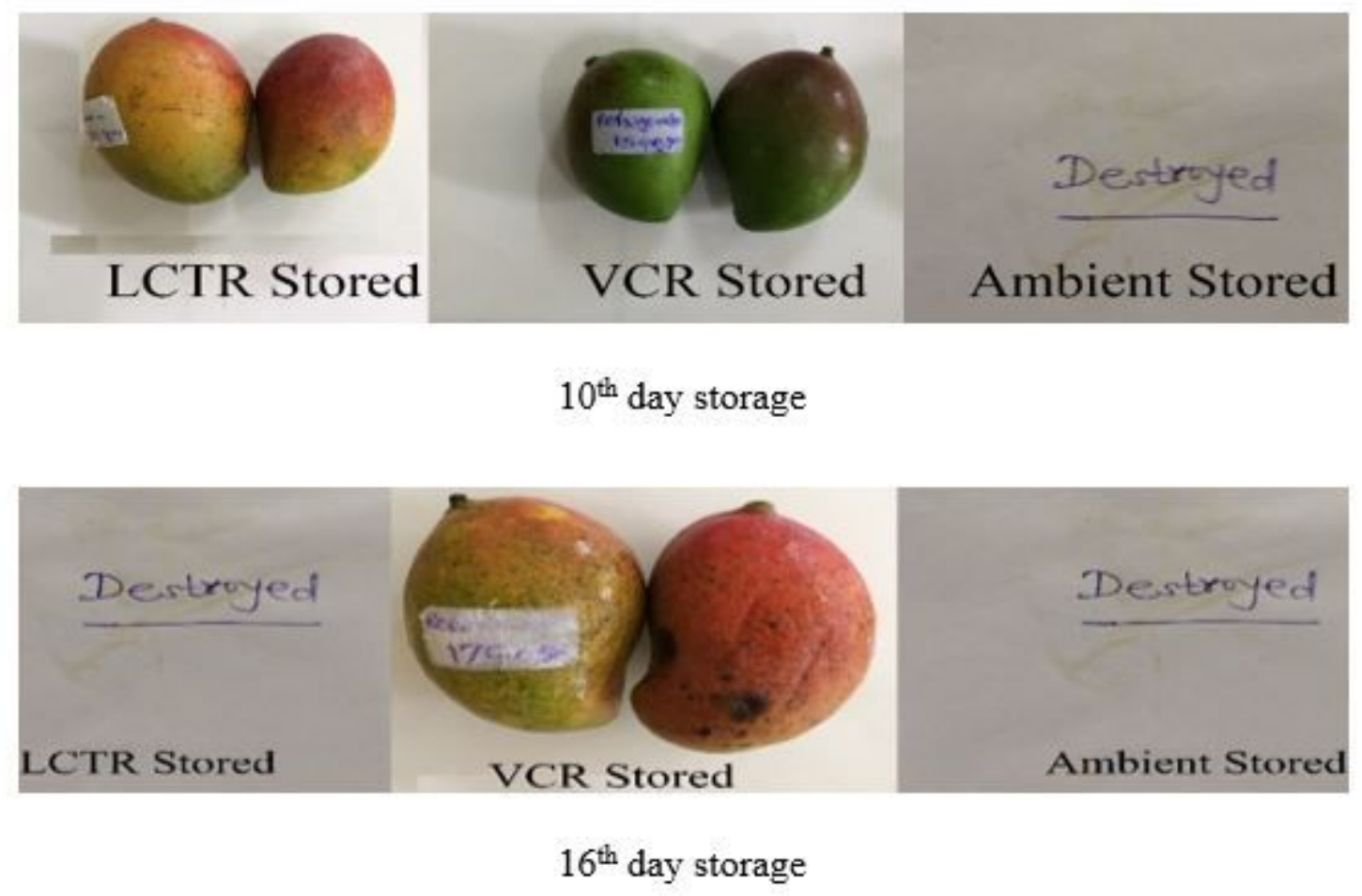

Figure 10

Visual appearance of mango during storage. 


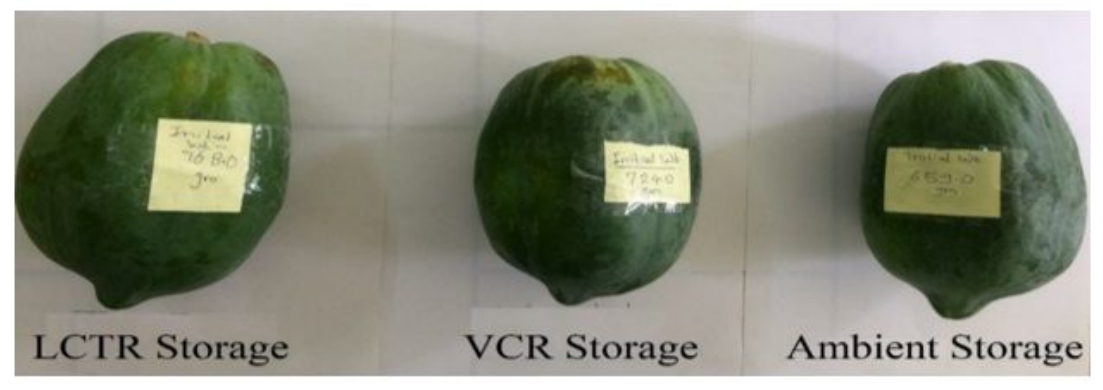

$0^{\text {th }}$ day storage

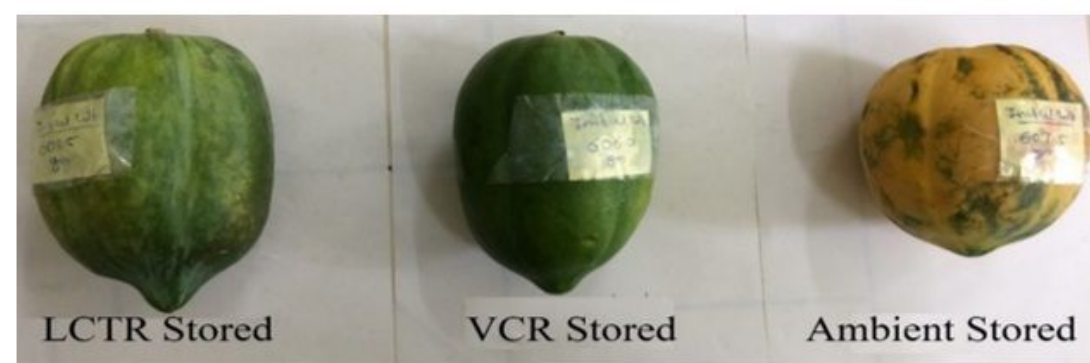

$4^{\text {th }}$ day storage

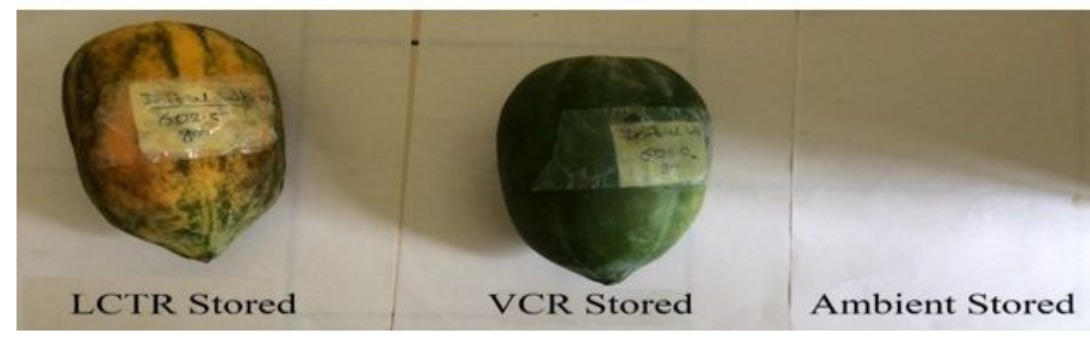

$13^{\text {th }}$ day storage

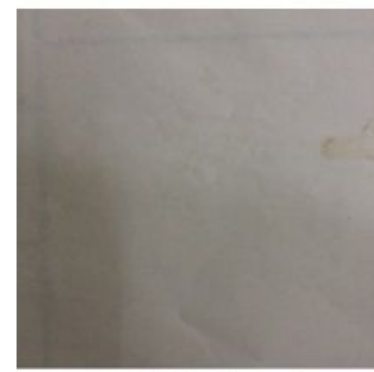

LCTR Stored

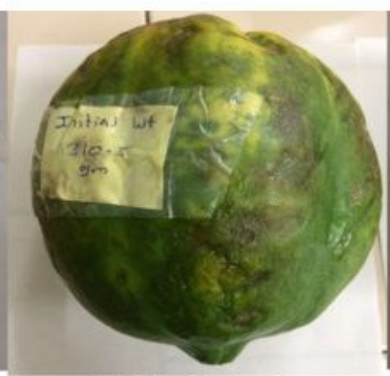

VCR Stored

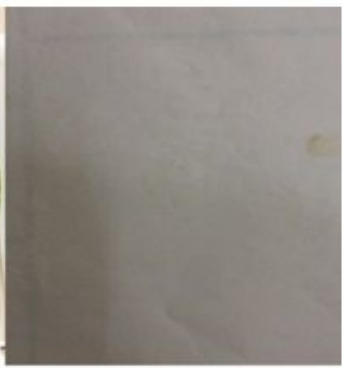

Ambient Stored

$16^{\text {th }}$ day storage

\section{Figure 11}

Visual appearance of papaya during storage. 

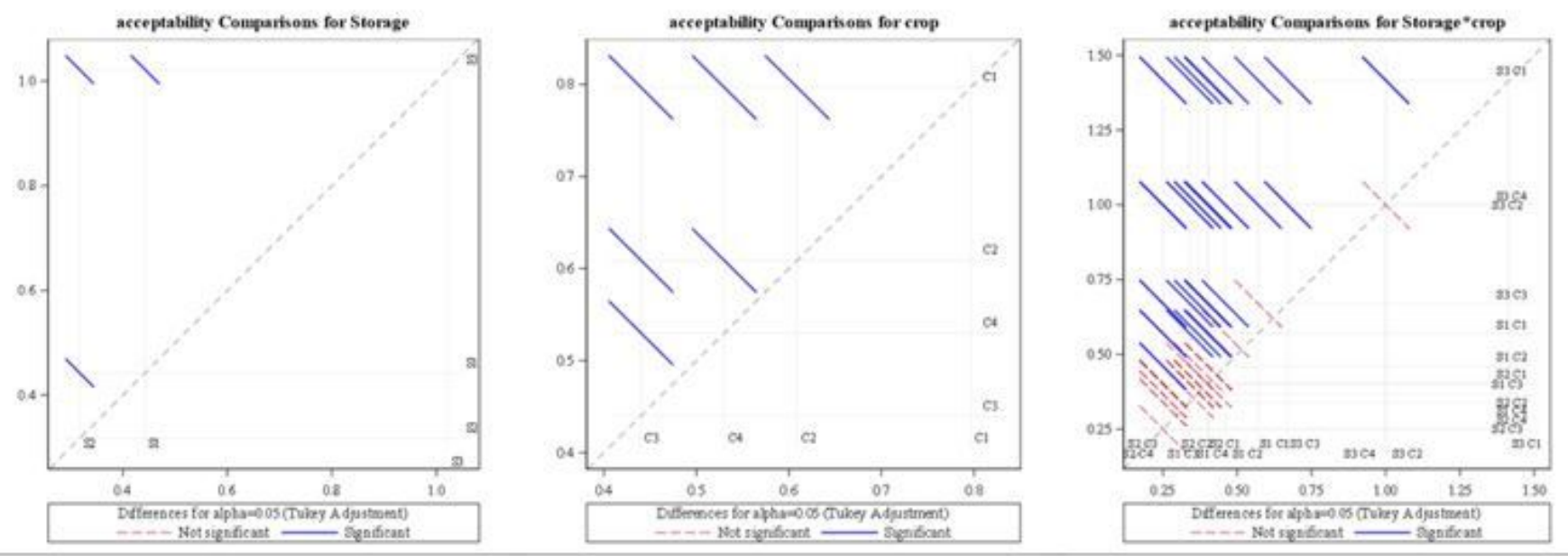

S1 - LCTR

C1 - Bitter gourd

C2 - Okra

$\mathrm{S} 2$ - VCR

C3 - Mango

C4 - Papaya

S3 - Ambient storage

\section{Figure 12}

Effect of storage system on average daily change of overall acceptability of crop 